\title{
Jury Trial as the Atavism of History
}

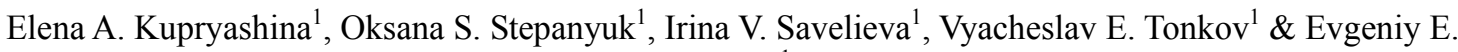 \\ Tonkov $^{1}$ \\ ${ }^{1}$ Belgorod State University, 85 Pobedy Street, Belgorod, the Belgorod region, Russia \\ Correspondence: Elena A. Kupryashina, Belgorod State University, 85 Pobedy Street, Belgorod, the Belgorod \\ region, 308015, Russia. E-mail: russia@prescopus.com
}

Received: June 19, 2017

Accepted: July 18, 2017

Online Published: August 30, 2017

doi:10.5539/jpl.v10n4p212

URL: https://doi.org/10.5539/jpl.v10n4p212

\begin{abstract}
Based on comparative-legal analysis of the jury trials development in Russia and foreign countries, the authors have shown, that broadening of jury trials powers, resulted in remoteness from finding the truth in criminal cases. Concession of the jury's opinion priority over the professionalism of the judge and the evidences, received in the process of investigation, put in jeopardy the fairness and objectivity of the court's decision. As a result, the court, based on the avesty of justicejury's conclusions, is forced, in some cases, to make a travesty of justice.
\end{abstract}

Keywords: jury trial, people's assessors, judge, truth, evidence, law, verdict, right

\section{Introduction}

As a legal phenomenon, the jury trial (or jury) originated in the 12th century, in the United Kingdom. The investigation with the participation of ordinary local people in land matters, and later in criminal cases, was forced into the application during the reign of Henry II (1154-1189) (Fowler, 2017).

Certainly, the jury of that far times does not similar to the modern. Jurors did not check the evidences. People gave the oath to the truth, based on their personal knowledge, impressions, known facts and decided the case by their final decision (verdict), which was reported to the judge. It was the beginning of such proceedings, where the jurors decided only the questions of facts, the decision of the law matters belonged to the professional judge.

Since then, jury trials have become widespread, mostly in countries of the common law, but in Russia, they were included in the legal system only as a result of the judicial reform in 1864. However, now, in countries with a common law system (Great Britain, the USA), also in European states with a continental system of law, there is a tendency to reduce the role of the jury trial by means of transformation of its basic elements, and over the long term, the abolition of its activities.

The relevance of comparative-legal investigation of the existing modifications of jury trial in the countries of Europe, America and Russia is conditioned by the possibility of reliance on the experience of both, positive and negative functioning of the jury trial models, with the aim of resolving the problems, arising in practice, and optimizing the regulation of national proceedings in this sphere.

\section{Methodology}

Various general scientific methods and means of logical cognition (system, analysis and synthesis, abstraction and formal logical approaches) are used in the work. The use of lingo-legal, historical, comparative-legal methods, as well as the methods of content analysis, facilitated the disclosure of the topic.

\section{Discussion and Results}

Now, within its traditional meaning, the jury trial has survived in common law countries (the United States, Great Britain) and some European (Austria, Belgium, Norway, and Switzerland). A panel, consisting of 8-12 jurors, separately resolving questions of facts and law, with the participation of 1-3 professional judges, takes verdicts on the matter of the most serious crimes.

In the modern world, many countries of continental Europe have completely abandoned the jury trials in its classical meaning (Germany, the Netherlands). For example, in Germany, citizens participate in the administration of justice in mixed courts, Schoffen courts, when 2-3 shoffens (non-professional judges), together with the judge, decide on the guilt or innocence of the defendant and on the imposition of a penalty. 
In Denmark, Greece, Italy, Finland, Sweden, professional judges, together with the jury, decide the questions of guilt and the assignment of punishment.

In modern Europe, various modifications of the jury trials are increasingly used. For example, in Austria, three judges and eight jurors consider criminal cases with probable punishment of more than 10 years and political crimes. At the same time, the jurors decide the guilt of the defendant and mete out the punishment together with the judges.

In Belgium, a jury trial, consisting of 12 jurors, participates practically only in the cases with a possible sanction of twenty or more years, and the decision is taken by secret ballot with a majority of at least eight jurors.

In Denmark, a jury trial participates in verdicts for the cases with a punishment of at least four years, political crimes, or the cases, threatening by the placement of an accused person in a psychiatric hospital.

In Norway, people's assessors are involved in the courts of the first instance - non-professional judges, and in the appeal court - a panel, consisting of ten jurors. Here, in spite of the acquittal, judges may sanction the second trial, if they consider that the evidences speak for the guilt of the accused person.

In Switzerland, the jury trial, consisting of 12 members, was abolished in all cantons, except for the canton of Geneva, remaining in federal courts, where it is used extremely rarely (Vidmar, 2003). The actual position of affairs in European countries and states of other continents, regarding the participation of the people's assessors in the judicial proceedings, indicates for a restrained, and, in some ways, even negative attitude towards this institution. And of course, there are certain reasons for this.

Russia (since 1993), and Spain (since 1995) have become the unique countries in Europe, that have restored the traditional jury trial. In Russia, since 1993, the Constitution of the Russian Federation (Article 47) has provided for the participation of jurors in the criminal trials.

English model of the Russian jury trial, copied by our legislator, was formed without taking into account the fact that "neither the emergence, nor the initial development of the English jury, was a reflection of democratic processes; its roots were nourished by other sources," first of all, it was the need for the expansion and centralization of the royal power (Kondratchik, 1991, p. 444-446).

At that time, the competition or the right to defense were out of the question, due to the British feudal principle: "no one can have a lawyer against his King" (Cairns, 1998, p. 138). For this reason, the Anglo-American model of criminal justice is still referred to as accusatory (accusatoire) in French-speaking (La Rosa, 2003, p. 26), and also often in English-speaking (Langer, 2007) sources.

In Russia, the jury trial was abolished on November 24, 1917, by the "Decree on the court", and in 1918 the "jury" was replaced by "people's assessors", whose number was reduced to six, and in 1923 - to two people. As a result, they finally renounced the legal proceedings with the participation of the jury.

In 1993, the jury trial was revived, but in a new Russia, by means of formalizing the country's Constitution. This consolidation of the court provisions has paramount importance, by virtue whereof "the renunciation of jury trial without changing the Constitution is simply impossible" (Demihey, 2003, p. 617). The modern world practice of fixing the jury trial institution in constitutions proceeds from three options (Http://worldconstitutions.ru/).

The main option is the situation, when the Constitution establishes the right of the accused person of trial by jury. This is Constitutional legislation of the United Kingdom (Article 39 of the Magna Carta of 1215), as well as the Constitution of Austria (Article 91), Belgium (Article 150), Greece (Article 97.1), the USA (the 6th Amendment, 1791) and Sweden (Article 2).

Another option is when the Constitution establishes the right of the accused person for considering his case by a court, conforming to international standards: fair, public trial, within a reasonable time, by an independent court, created in accordance with the law. Examples include the constitutions of the Kingdom of the Netherlands (Article 17), Finland (Article 21) and France (Article 7).

The third option is the consolidation in the Constitution the right of citizens to participate in the administration of criminal justice as jurors: the Constitution of the Kingdom of Denmark (Article 65.2), the Kingdom of Spain (Article 125), the Republic of Macedonia (Article 103) and the Republic of Croatia (Article 118).

Thus, the jury trial is fixed as a legal institution at a constitutional level in 28 of 45 European states, and the right of the accused person to a jury trial is in the constitutions of 22 states (Dudko, 2013, p. 99-100).

Since the time of revival in Russia in 1993, the court with the participation of jurors has also been criticized for the verdicts brought to them (Fokov, 2009, p. 2-5), due to the inability of the jury to administer justice in a 
qualitative way. It is known, that throughout the history of its activities, jury trials in Russia have made more acquittals, than the ordinary courts. The percentage of acquittals, made by jurors, is high even today (in 2015, $11 \%$ of considered cases), whereas the share of acquittals in courts without their participation, does not exceed $1 \%$.

In 2001, it was proposed to extend the jury trial, except for federal subject courts to the district courts, as the means of anti-corruption in the judicial system of Russia (Vetrova, 2001, p. 267).

The jury trial in modern Russia is not a norm, it is a certain phenomenon or a perfect feature of the proceedings (it is more the exception, than the rule).

In Russia, in 2015 , about $70 \%$ of criminal cases resulted in sentencing in the process of case consideration, both in a special procedure for the trial and with the conclusion of a pre-trial cooperation agreement. In remaining $30 \%$ of cases, considering per standard procedure, the number of defendants, whose cases were considered by the jury, was $0,06 \%$ (Http://www.cdep.ru/index.php?id=79). For comparison, now in the United States, 97,4\% of criminal cases are resolved by virtue of plea bargaining.

A.D. Boykov, speaking in general against the jury trials, emphasizes, that in England, in the United States, in Canada and France - "the jury trial considers only 1- 4\% of all criminal cases" (Boykov, 2002, p. 98).

A.V. Pobedkin believes, that the jury trial is "ill-adapted to the establishment of objective truth", although he makes the reservation, that "with the existing legal consciousness of professional judges, their attitude to the possibility of acquittals, the refusal from a jury trial is premature" (Pobedkin, 2013, p. 248).

The current stage of the jury trial development in Russia can rightfully be called revolutionary. In an annual address to the Federal Assembly in 2015, the President of the Russian Federation, V.V. Putin expressed his opinion on the need to reform the jury institution. In particular, the head of the state proposed "to strengthen the role of the jury institution, to expand the number of cases, that they can consider... to think about reducing the number of jurors to 5-7 people, while preserving the full autonomy and independence of the jury in making decisions" (Http://kremlin.ru/events/president/news/).

Developing these provisions at the All-Russian Meeting of Judges in February 2016, the President of the country called the jury institution ineffective, in view of the reduced number of considered cases, although as many citizens as possible should be able to choose this particular form of justice, therefore, in his opinion, it should be extended to the District Courts (Http://kremlin.ru/events/president/news/).

March 14, 2016, the package of relevant presidential draft laws was submitted to the State Duma of the Federal Assembly of the Russian Federation, which in June gained the status of laws. Among them is the Federal Law from June 23, 2016 № 190-FZ, forcing into application the new form of criminal proceedings in the district courts from June 1, 2018.

Undoubtedly, the jury trial is a constitutionally fixed form of justice administration, the democratic principle in a legal, socially-oriented state, inherent in the leading judicial systems. And in the form, in which it existed before the adoption of this package of presidential bills, the true manifestation of "people's justice" existed within sufficient limits and the amounts, needed at the present stage of development of the national judicial system.

\section{Conclusions}

In our opinion, in the expanding tendency of the jury trial, not everything is perfect from the point of view of such decisive step consequences (even without considering the scope of organizational and technical problems).

Emotions, intuition, psychological features of the person, mood, material difficulties, personal family problems are the incomplete list of factors, that exerts an unquestionable influence on the jurors and the interpretation of the considered case.

By increasing the range of possibilities for jury trial, may be we make a tragic error, when the judge's competent opinion, based on professional examination and assessment of evidences, is substituted by the person's psychological, personal attitude to what has happened. Is it justified to put intuition above the law?

Certainly, this approach can be useful for certain categories of cases. For example, the use of the jury institution in Russia is unmistakable in cases, where the right to trial by jury is also a guarantee of the right to life. It is no accident, that the establishment of an exceptional penalty for particularly serious crimes against life, by virtue of the provisions of Part 2 of Article 20 of the Constitution of the Russian Federation, is possible only if the accused person is given the right of trial by jury.

By the way, other cases of realization the right to "public court" are not called by the Basic Law, delegating its 
development to the federal legislature (Part 2 of Article 47). At the same time, the expansion of this practice in the format of future innovations seems to be ill-conceived and insufficiently justified.

Any legal goal needs the means to ensure its achievement. If the establishment of truth in a criminal case is considered as one of the priority objectives of the trial, then whether the jury trial is an adequate means to achieve this goal. After all, it is often enough when the jury's conclusions contradict the judge's opinion and are far from the truth. And if so, the entire construction of the legal system, its purpose and principles are under threat. The Principles are not derived from goals, but are defined simultaneously with them.

Truth can not be formed solely on the emotional background. Only a professional judge can competently answer the question, whether the evidences, presented by the prosecution, are reliable and sufficient, and give the correct answers to every question, to be resolved when deciding the sentence.

Moreover, the decision on the basis of the jury conclusion, in our opinion, actually disavows Article 8 of the Code of Criminal Procedure, according to which, justice in a criminal case is executed only by a court in the Russian Federation. It is generally known, that this article only fixes the provision, arising from the content of the Part 1 of Article 118 of the Constitution.

The court executes justice, it also takes the decision, but sometimes it is based on the conclusions of the jury, which do not correspond to the truth in the criminal case. Thus, the court, based on the jury's conclusions, is forced, in a number of cases, to make a travesty of justice.

\section{References}

Boykov, A. D. (2002). The Third Power in Russia. M.: Yurlitinform. Book. 2: Longitudinal Reform. 280 p. (In Russian).

Cairns, D. J. A. (1998). Advocacy and the Making of the Adversarial Criminal Trial, 1800-1865. Oxford.

Demichev, A. A. (2003). Comparative-legal study of jury trials in Russia (history and modernity): extended abstract of a thesis for a Doctor's of Law degree. N. Novgorod, 481 p. (in Russian).

Dudko, N. A. (2013). The right of the accused to trial by jury in the system of constitutional human rights and civil responsibility. Izvestia of Altai State University. Edition "The State and the Law". Volume 2. Pp. 99-100. (In Russian).

Fokov, A. P. (2009). Justice with the participation of citizens in Russia. Russian Judge. No8. Pp. 2-5. (In Russian)

Fowler, R. (2017, January). Feature story: Henry II: father of the common law. Tennessee Bar Journal.

Kondratchik, A. L. (1991). English jury trial: historical roots and evolution. Soviet state and law, (6), 133-138. (In Russian).

La Rosa, A. (2003). Juridictions pénales internationales: la procédure et la prevue. P.U.F, Paris, 507 p. https://doi.org/10.4000/books.iheid.558

Langer, M. (2007). Revolution in Latin American Criminal Procedure: Diffusion of Legal Ideas from the Periphery. The American Journal of Comparative Law, IV(4), 617-676. https://doi.org/10.1093/ajcl/55.4.617

Pobedkin, A. V. (2013). Criminal process: the state outside of the law. M.: Yurlitinform, 248 p. (In Russian).

Vetrova, G. N. (2001). Does the justice need people's representatives? State and Law at the Turn of the Century. M., Pp. 191-197. (In Russian).

Vidmar, N. (2003). World Jury Systems. Oxford, N.Y., 482 p.

\section{Copyrights}

Copyright for this article is retained by the author(s), with first publication rights granted to the journal.

This is an open-access article distributed under the terms and conditions of the Creative Commons Attribution license (http://creativecommons.org/licenses/by/4.0/). 